\title{
Cocaine induced hippocampi infarction
}

\author{
Sarkis Gibran Morales Vidal, Alejandro Hornik, Christopher Morgan
}

Neurology Department, Loyola University Medical Center, Maywood, Illinois, USA

Correspondence to Dr Sarkis Gibran Morales Vidal, smoralesvidal@lumc.edu

\section{Summary}

A middle age man presented with disorientation and memory impairment due to bilateral hippocampal strokes secondary to cocaine use. This is the second report of cocaine induced hippocampi ischaemic strokes. In contrast to the previous report, this middle age man did not have cardiac arrest.

\section{BACKGROUND}

This is the second case report of cocaine induced hyppocampi stroke. In the previous case report, the patient suffered from cardiac arrest. In contrast, this middle age man only had disorientation and impaired memory.

\section{CASE PRESENTATION}

A middle age man was brought by coworkers to the emergency room due to disorientation and memory difficulties. His medical history was significant for hypertension, dyslipidaemia and coronary artery disease. Social history was pertinent for 'occasional cocaine use' and for drinking two to three beers per day. He used cocaine 2 days before. He stopped smoking cigarettes 3 years ago. Blood pressure was $160 / 85 \mathrm{~mm} \mathrm{Hg}$. The rest of vital signs were normal.

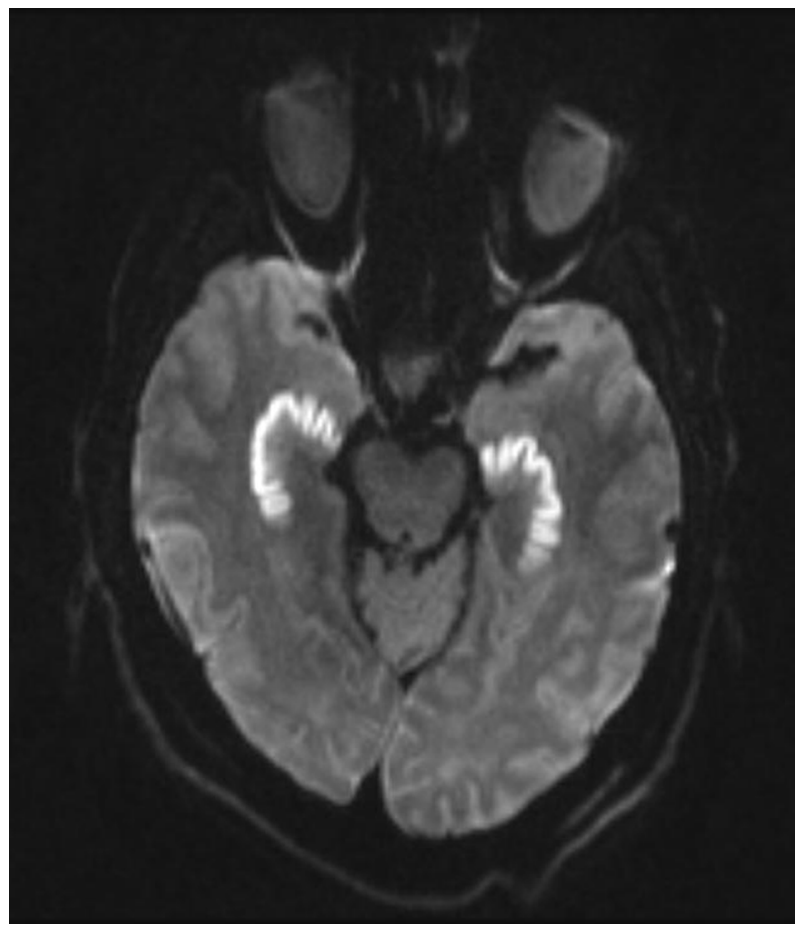

Figure 1 Diffusion restricted image (DWI) showing increase signal change of hippocampi.
He was alert and disoriented to time and space but not to person. Language functions were intact. Attention, short term memory and delay recall were impaired. Remote memory was intact. Rest of the neurologic examination was normal. Brain MRI showed restricted diffusion of the hippocampi (figures 1 and 2). In addition, there were small areas of restricted diffusion in the left parietal white matter, left posterior corona radiata, left superior temporal cortex, left lentiform nucleus, left occipital white matter and left inferior cerebellum. Urine drug screen was positive for cocaine. ECG, transesophageal echocardiogram and carotid duplex ultrasound showed no significant abnormalities. There were no heart rhythm abnormalities reported on the telemetry report. Antinuclear antibodies, lupus anticoagulant, anticardiolipin antibodies, antibodies to extracted nuclear antigen (ENA-5) and rheumatoid fac-

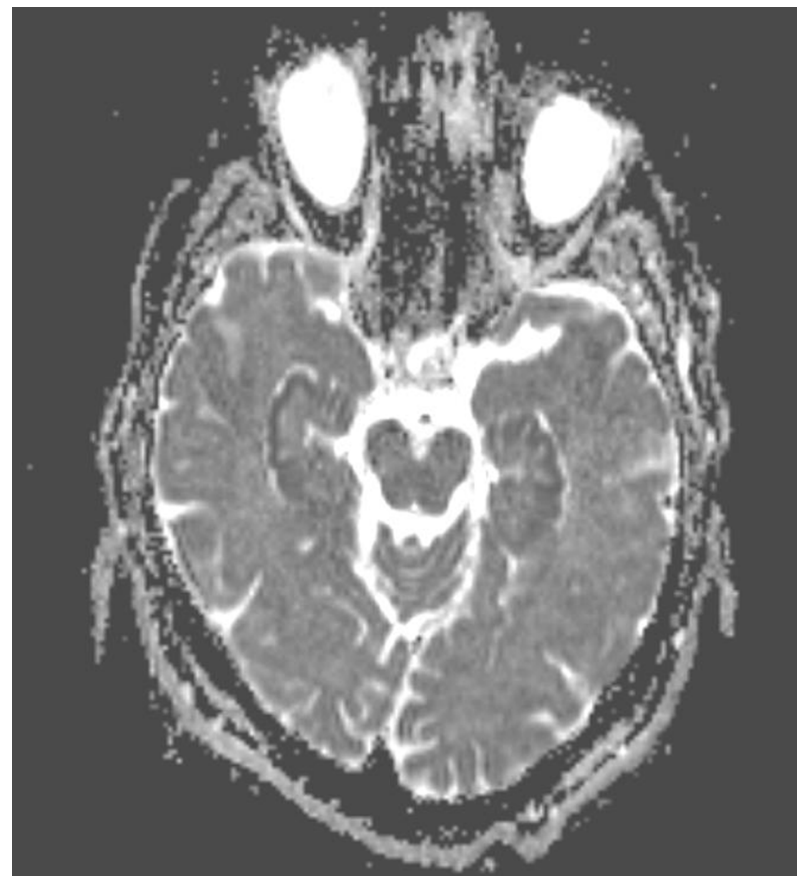

Figure 2 Apparent diffusion coefficient map showing low signal change of hippocampi indicative of restricted diffusion. 


\section{BMJ Case Reports}

tor were all normal. He was discharged home on aspirin and antihypertensive medications.

\section{DIFFERENTIAL DIAGNOSIS}

- Hypoxic ischaemic brain injury from cardiac arrest

- Hypoxic ischaemic brain injury from respiratory failure

- Global cerebral hypoxia due to other causes.

\section{OUTCOME AND FOLLOW-UP}

Two month later, the patient continued to have memory impairment. Neuropsycholocic evaluation showed impaired executive functioning secondary to poor attention and memory disturbances. His mood was normal. A follow-up MRI done 2 months later showed increase T2 signal change of hippocampi with resolution of restricted diffusion. He was considered disable to return to work due to neurocognitive impairment.

\section{DISCUSSION}

Central nervous system regions with increase risk for hypoxic injury include hyppocampi, striatum, Purkinje cells of the cerebellum and layers 3 and 5 of the neocortex. ${ }^{1}$ The CA1 region is the most vulnerable area to ischaemia in the hippocampus. Increase susceptibility to neuronal death following cerebral ischaemia has been demonstrated in animal models. Several causes of global cerebral ischaemia, for example cardiac arrest, may lead to isolated infarction in these areas. The first case report of cocaine induced hippocampal stroke occurred in the context of cardiac arrest. ${ }^{2}$ Our patient had no documented history of either cardiac or respiratory arrest.

Cocaine may cause ischaemic or haemorrhagic stroke. Cocaine related cerebral infarction was first reported with intramuscular cocaine use. ${ }^{3}$ Cocaine induced vasoconstriction is considered to be the main mechanism leading to cerebral ischaemia. Metabolites may remain active for hours or even days following cocaine use. ${ }^{4}$ Cocaine induced vasospasm can persist further than its half life due to the presence of its major metabolites, benzoylecgonine and norcocaine. ${ }^{5}$ In addition, bradykinin-mediated endothelial relaxation is also impaired in chronic cocaine users. ${ }^{6}$ Cardioembolic ischaemic stroke may result from cardiac ischaemia secondary to cocaine induced coronary vasoconstriction. Other postulated mechanisms of cocaine induced ischaemic stroke include enhanced platelet aggregation and increased coagulability. ${ }^{7}$ In addition, ethanol may enhance cocaine effects.

\section{Learning points}

- Sudden memory impairment may be the initial presentation of bilateral hippocampi cerebral infarction.

- Cocaine use should be investigated in patients with hippocampal infarction.

- Hippocampi infarction may occur in cocaine users without cardiac arrest or cardiomyopathy.

\section{Competing interests None.}

Patient consent Obtained.

\section{REFERENCES}

1. Cervós-Navarro J, Diemer NH. Selective vulnerability in brain hypoxia. Crit Rev Neurobiol 1991;6:149-82.

2. Bolouri MR, Small GA. Neuroimaging of hypoxia and cocaine-induced hippocampal stroke. J Neuroimaging 2004;14:290-1.

3. Brust JC, Richter RW. Stroke associated with cocaine abuse-? N Y State J Med 1977; 77:1473-5

4. Herning RI, King DE, Better WE, et al. Neurovascular deficits in cocaine abusers. Neuropsychopharmacology 1999;21:110-8.

5. Konzen JP, Levine SR, Garcia JH. Vasospasm and thrombus formation as possible mechanisms of stroke related to alkaloidal cocaine. Stroke 1995;26:1114-8

6. Havraanek EP, Nademanee K, Grayburn PA, et al. Endothelium - dependent vasorelaxation is impaired in cocaine artheriopathy. J Am Coll Cardiol 1996;28:1168-74.

7. Jennings LK, White MM, Sauer CM, et al. Cocaine-induced platelet defects. Stroke 1993;24:1352-9.

This pdf has been created automatically from the final edited text and images.

Copyright 2012 BMJ Publishing Group. All rights reserved. For permission to reuse any of this content visit http://group.bmj.com/group/rights-licensing/permissions.

BMJ Case Report Fellows may re-use this article for personal use and teaching without any further permission.

Please cite this article as follows (you will need to access the article online to obtain the date of publication).

Morales Vidal SG, Hornik A, Morgan C. Cocaine induced hippocampi infarction. BMJ Case Reports 2012;10.1136/bcr.03.2012.5998, Published XXX

Become a Fellow of BMJ Case Reports today and you can:

- Submit as many cases as you like

- Enjoy fast sympathetic peer review and rapid publication of accepted articles

- Access all the published articles

- Re-use any of the published material for personal use and teaching without further permission

For information on Institutional Fellowships contact consortiasales@bmjgroup.com

Visit casereports.bmj.com for more articles like this and to become a Fellow

Keep up to date with all published cases by signing up for an alert (all we need is your email address) http://casereports.bmj.com/cgi/alerts/etoc 